\title{
Trematoda Metorchis Bilis (Braun 1790) as the Remaining Problem of Sanitation in the Regions of the North Caucasus
}

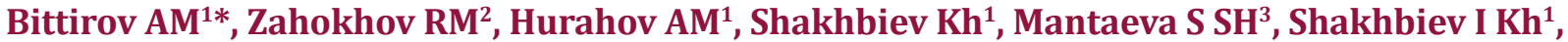 \\ Bittirova $\mathrm{AA}^{1}$ and Begieva $\mathrm{SA}^{1}$ \\ ${ }^{1}$ Department of Veterinary Medicine, Russia \\ ${ }^{2}$ Department of Hospital Surgery, Russia \\ ${ }^{3}$ Department Zoology and Bioecology, Russia
}

*Corresponding author: Bittirov AM, Department of Veterinary Medicine, Russia

ARTICLE INFO

Received: 幽 June 26, 2019

Published: 蔧 July 01, 2019

Citation: Bittirov AM, Zahokhov RM, Hurahov AM, Shakhbiev Kh, Mantaeva S SH, Shakhbiev I Kh, Bittirova AA, Begieva SA. Trematoda Metorchis Bilis (Braun 1790) as the Remaining Problem of Sanitation in the Regions of the North Caucasus. Biomed J Sci \& Tech Res 19(2)-2019. BJSTR. MS.ID.003279.

Keywords: Kabardino-Balkaria; Flat Zone; The Soil; Egg; Trematodes Metorchis bilis

\begin{abstract}
In the last decade in the North Caucasus region, the number of street dogs and wild carnivores increased 3-5 times, which led to an increase in soil contamination with eggs Metorchis bilis (Braun 1790). In particular, the number of samples soil and feces with the presence of trematode eggs of the Metorchis bilis (Braun 1790) species in the watering places of animals increased to $95.71 \%$, in the soil of pasture territories increased to $97.81 \%$, in the soil of vegetable gardens increased to $95.00 \%$, in the soil of the coastal areas of the rivers up to 93.22-100\%, which indicates a high level of pollution of the infrastructure areas of Kabardino-Balkaria with) eggs Metorchis bilis (Braun 1790 the current sanitary condition of the flat areas of Kabardino-Balkaria, when of the soil is polluted with eggs Metorchis bilis (Braun 1790), requires urgent measures to reduce the number of patients with metorchosis dogs by organizing deworming of the entire population of carnivores 4 times a year (in spring, summer, autumn and winter ) with the use of drugs based on praziquantel, albendazole, triclabendazole and fenbendazole and other highly effective drugs.
\end{abstract}

\section{Introduction}

Metorhosis carnivores, caused by the trematode of the species Metorchis bilis (Braun 1790), of wild canids in the Russian Federation belong to almost forgotten invasions, since the 1980s there have been few works on the problems of the epidemiology of this invasion [1-7]. Over the past 20 years, the incidence of metorchosis of dogs and wild canines has increased by 6-10 times [6-10]. The invasion of the larval metorchosis in animals (pig, wild boar) became enzootic for the regions of the North Caucasus. The epizootic situation on metorchosis is dynamically complicated by the formation of regional foci of invasion, especially in dogs in rural areas with inland water bodies [11-16]. Currently, in 10 species of animals, metorchosis has a high prevalence rate [17-20]. In the regions of the North Caucasus, the infection by canids with trematodes of the species Metorchis bilis (Braun 1790) is 15-27\% [21-35]. In Russia, the species Metorchis xanthosomus is often found in predatory animals in the Ob-Irtysh basin of the Russian Federation with an EI of 19-35\% [1-35].

\section{Materials and Methods}

The work was carried out on the basis of the laboratory of parasitology of the Caspian Zonal Veterinary Research Institute in 20152018. For this, more than 1,500 soil samples were taken, samples of feces dogs for identifying trematode Metorchis bilis (Braun 1790) from different places in the lowland zone (Tersky, Maysky, Prokhladnensky areas). The experiments were carried out using modern methods MUK "Methods of sanitary-parasitological studies." Data subjected to statistical processing of the program "Biometrics". 


\section{Results}

The sanitary and hygienic state of the soils of the flat zone (Tersky, Maysky, Prokhladnensky districts) is poorly studied due in terms them contamination with eggs Metorchis bilis. Studies of soil samples and feces of dogs in the context of areas for contamination with eggs of Metorchis bilis are presented in Table 1. It can be seen in the flat zone $31,40-45,20 \%$ of soil and feces samples dogs are contaminated with eggs Metorchis bilis (an average of 10,90 $\pm 0,70$ specimens per g soil and feces) (Table 1).
Relatively more eggs Metorchis bilis (Braun 1790) were found in the soils of the Prokhladnensky district (38.40\% of soil samples), which is associated with a high density of dogs and wild carnivorous animals infected with metorchosis, and the formation of a large number of biotopes of intermediate hosts in the nearlake reservoirs (rivers, lakes, fish ponds). In addition, about $90 \%$ of the dogs in the villages of the Tersky, Maysky and Prokhladnensky districts do not degelmintate and they worsen the epizootic situation on metorchosis caused by trematodes Metorchis bilis (Tables 1-3).

Table 1: Sanitary and hygienic condition of soils in the flat zone of Kabardino-Balkaria due to their contamination with eggs Metorchis bilis (Braun 1790).

\begin{tabular}{|c|c|c|c|c|}
\hline Study area & $\begin{array}{c}\% \text { contaminated } \\
\text { samples soil and feces }\end{array}$ & $\begin{array}{c}\% \text { contaminated } \\
\text { samples soil and feces }\end{array}$ & $\begin{array}{c}\% \text { contaminated } \\
\text { samples soil and feces }\end{array}$ & $\begin{array}{l}\text { Number of eggs species Metorchis } \\
\text { bilis in } 1 \text { g samples soil and feces, } \\
\text { ekzemplyar }\end{array}$ \\
\hline of Tersky & 500 & 157 & 31,40 & $7,8 \pm 0,5$ \\
\hline of Maysky & 500 & 193 & 38,60 & $8,6 \pm 0,7$ \\
\hline of Prokhladnensky & 500 & 226 & 45,20 & $10,3 \pm 0,9$ \\
\hline Total: & 1500 & 576 & - & - \\
\hline Average: & - & - & 38,40 & $10,90 \pm 0,70$ \\
\hline
\end{tabular}

Table 2: Dynamics of soil and feces contamination in the flat zone by eggs of the species Metorchis bilis (Braun 1790) (according to coproovoscopy).

\begin{tabular}{|c|c|c|c|c|}
\hline Year & $\begin{array}{c}\text { Investigated } \\
\text { soil and feces samples, } \\
\text { ekzemplyar }\end{array}$ & $\begin{array}{c}\text { Discovered soil and feces samples with } \\
\text { eggs species Metorchis bilis (Braun } \\
\text { 1790), ekzemplyar }\end{array}$ & $\begin{array}{c}\text { \% contaminated } \\
\text { samples soil and } \\
\text { feces }\end{array}$ & $\begin{array}{c}\text { Amount eggs species Metorchis bilis } \\
\text { (Braun 1790) } \\
\text { in 1 gamples soil and feces, } \\
\text { ekzemplyar }\end{array}$ \\
\hline 2015 & 100 & 28 & 28,0 & $8,4 \pm 0,4$ \\
\hline 2016 & 100 & 34 & 34,0 & $9,6 \pm 0,6$ \\
\hline 2017 & 100 & 42 & 42,0 & $11,9 \pm 0,8$ \\
\hline 2018 & 100 & 49 & 49.0 & $13,7 \pm 1,0$ \\
\hline Total: & 400 & 153 & - & - \\
\hline Average: & - & - & 38,30 & $10,90 \pm 0,70$ \\
\hline
\end{tabular}

Table 3: Dynamics of contamination of soil and feces of dogs on pastures of the flat zone with eggs of the species Metorchis bilis (according to coproovoscopy data).

\begin{tabular}{|c|c|c|c|c|}
\hline Year & $\begin{array}{c}\text { Investigated } \\
\text { soil and feces samples, } \\
\text { ekzemplyar }\end{array}$ & $\begin{array}{c}\text { Discovered soil and feces samples } \\
\text { with eggs species Metorchis bilis } \\
\text { (Braun 1790), ekzemplyar }\end{array}$ & $\begin{array}{c}\text { \% contaminated } \\
\text { samples soil and } \\
\text { feces }\end{array}$ & $\begin{array}{c}\text { Amount eggs species Metorchis bilis } \\
\text { (Braun 1790) in 1 g samples soil and } \\
\text { feces, ekzemplyar }\end{array}$ \\
\hline 2015 & 100 & 37 & 37,0 & $11,3 \pm 0,7$ \\
\hline 2016 & 100 & 48 & 48,0 & $12,5 \pm 0,9$ \\
\hline 2017 & 100 & 60 & 60,0 & $14,8 \pm 1,1$ \\
\hline 2018 & 100 & 82 & 82.0 & $17,6 \pm 1,3$ \\
\hline Total: & 400 & 227 & - & - \\
\hline Average: & - & - & 56,75 & $13,80 \pm 1,00$ \\
\hline
\end{tabular}

When studying the dynamics of soil pollution in 2015-2018 the invasive elements of Metorchis bilis (Braun 1790) in the flat zone (Tersky, Maysky, Prokhladnensky districts) show a gradual increase in contamination of soil samples and feces of dogs from 28.0 to
$49.0 \%$ (average $38.30 \%$ ). The increase in the number of eggs Metorchis bilis (Braun 1790) in $1 \mathrm{~g}$ of soil samples and feces from 8.4 \pm 0.4 ekz. up to $13.7 \pm 1.0 \mathrm{ekz}$. (on average $10.90 \pm 0.70$ ekz. per $1 \mathrm{~g}$ of soil and feces) is associated with complete non-compliance with 
the rules for keeping dogs in the local population, non-compliance with sanitary and hygienic norms, terms and frequency of deworming of carnivorous animals against metorchosis, approved by the Rosselkhoznadzor and the Veterinary Department of the Ministry Agriculture of the Russian Federation (Table 2).

The dynamics of contamination of pasture soils and of feces dogs with eggs Metorchis bilis (Braun 1790) in the lowland zone (Terek, Maysky, Prokhladnensky districts) was characterized by an increase in soil contamination and samples fecal from 37.0 to $82.0 \%$ (on average $56.75 \%$ ), with an increase in the number of eggs per 1 $\mathrm{g}$ of soil and feces from $11.3 \pm 0.7$ to $17.6 \pm 1.3 \mathrm{ekz}$. (average value of $13.80 \pm 1.00$ ekz. per $1 \mathrm{~g}$ of soil and feces), which indicates the likely formation of persistent epizootically dangerous for dogs, wild carnivores' animals, pigs and wild boars of metorchosis invasion in the North Caucasus region (Table 3). In the last decade in the North Caucasus region, the number of street dogs and wild carnivores increased 3-5 times, which led to an increase in soil contamination with eggs Metorchis bilis (Braun 1790). In particular, the number of samples soil and feces with the presence of trematode eggs of the Metorchis bilis species in the watering places of animals increased to $95.71 \%$, in the soil of pasture territories increased to $97.81 \%$, in the soil of vegetable gardens increased to $95.00 \%$, in the soil of the coastal areas of the rivers up to 93.22-100\%, which indicates a high level of pollution of the infrastructure areas of Kabardino-Balkaria with eggs Metorchis bilis (Braun 1790) (Table 4).

Table 4: Objects contaminated with eggs Metorchis bilis (Braun 1790) in the Kabardino-Balkarian Republic (according ovoscopy soil and feces).

\begin{tabular}{|c|c|c|c|c|}
\hline Objects & $\begin{array}{c}\text { Number of objects, } \\
\text { units }\end{array}$ & $\begin{array}{c}\text { Investigated } \\
\text { samples soil and feces, } \\
\text { units }\end{array}$ & $\begin{array}{c}\text { Samples soil and feces } \\
\text { with eggs species Metorchis } \\
\text { bilis (Braun 1790), units }\end{array}$ & $\begin{array}{c}\text { \% contaminated samples soil } \\
\text { and feces }\end{array}$ \\
\hline Animal Watering Places & 28 & 560 & 536 & 95,71 \\
\hline Pasture areas & 16 & 320 & 313 & 97,81 \\
\hline Garden territories & 32 & 640 & 608 & 95,00 \\
\hline Household territories & 56 & 1120 & 1044 & 93,22 \\
\hline Riverside & 14 & 280 & 280 & 100 \\
\hline Average: & - & - & 56,75 & $13,80 \pm 1,00$ \\
\hline
\end{tabular}

\section{Discussion}

The data obtained indicate a constant from year to year dynamic soil pollution in the flat zone in the territories of pastures, watering places for animals, in the coastal strip, and also in the territories of homeowners with eggs Metorchis bilis (Braun 1790), which is consistent with the data of A.V.Uspensky, S.Sh. Kabardiev, 2014., on the need for continuous monitoring of the problems of regional pathology of dangerous zoonoses in the Central Caucasus region and the sanitary status of the steppe of regions the of North Caucasus regarding contamination with trematode eggs Metorchis bilis.

\section{Conclusion}

The current sanitary condition of the flat areas of KabardinoBalkaria, when of the soil is polluted with Metorchis bilis (Braun 1790), requires urgent measures to reduce the number of patients with metorchosis dogs by organizing deworming of the entire population of carnivores 4 times a year (in spring, summer, autumn and winter ) with the use of drugs based on praziquantel, albendazole, triclabendazole and fenbendazole and other highly effective drugs.

\section{References}

1. Shakhbiev I, Shakhbiev Kh (2015) Epizootological analysis of bio and geohelminths of wild dogs (wolfes) in the territory of the Chechen Republic. J Questions of regulatory legal regulation in veterinary medicine №4, p. 80-83.

2. Arkhipova DR, Arkhipov IA (2004) Zoogeography of dogs helminthes in Russia. Materials dokl sci Conf VIGIS “Theory and practice of combating parasitic diseases Moscow, p. 42-44.
3. Atabieva Zh A, Bichieva MM, Kolodiy IV, Shikhalieva MA, Sarbasheva MM (2012) Forecasting of epizootic and epidemic situation on zoonoses invasions in the south of Russia. J Veterinary pathology 39: 119-122.

4. Gazimagomedov MG, Kabardiev S Sh, Magomedov OA, Begiev S Zh, Karpushchenko KA, et al. (2016) Complex antiparasitic composition "Azinal plus" -3 for chemotherapy and prevention of trichuriasis, ankylostomaosis and echinococcosis of dogs. patent RUS 2614711.

5. Zhekamukhova MZ, Atabieva Zh A, Bittirova AA, Sarbasheva MM Shikhalieva MA (2012) Ecological and species composition of endoparasites fauna and epidemiological characteristic of zoonoses in Kabardino-Balkaria. Agriculture and Forestry 18: 146

6. Sarbasheva MM, Atabieva Zh A (2013) Epidemiological analysis of human nematodes in Kabardino-Balkaria. J Success of modern natural science p. 25-26.

7. Shikhalieva MA (2012) The structure of parasitocenosis of animals taking into account the vertical zone of the Northern Caucasus region. J Veterinary pathology 40: 109-113.

8. Bittirov AM (2013) The epidemiological situation in animal and human helminthoses in Kabardino-Balkaria. 21: 29-33.

9. Mantaeva S Sh, Shikhalieva MA, Sarbasheva MM, Begiev SZ, Golubev AA et al. (2012) Epizootological assessment of helminthes of dogs and wild dogs in Kabardino-Balkaria. J Agrarian Science p. 31-32.

10. Sarbasheva MM, Atabieva Zh A, Bichieva MM, Shikhalieva MA, Golubev AA, et al. (2011) Epizootological significant helminth fauna of wild animals of the reserved territories of the North Caucasus. J Veterinary Pathology 4(38): 99-102.

11. Kanokova AS, Sarbasheva MM, Kazancheva LK (2010) Sanitary and Parasitologica research of infrastructure facilities in the settlements of the Kabardino-Balkaria. Materials of the All-Russian Scientific pp. 47-52.

12. Vasilevich FI, Kalabekov MI, Aliev Sh K, Sarbasheva MM (2010) Biodiversity, biogeography and epidemiological monitoring of zoonoses of dogs and wild dogs' family (Canidae) in the North Caucasus region. Nalchik: Poligraphservis LLC pp. 168. 
13. Vasilevich FI, Kalabekov MI, Eshokov R Kh, Sottaev M Kh (2010) Sanitary education of the population and ways to ensure hygienic safety in relation to zoonotic invasions. Nalchik-Moscow p. 68.

14. Shikhalieva MA, Sarbasheva MM (2012) Epizootic situation on zoonoses invasions in the of Russia. J Veterinary Pathology 3(40): 103-105.

15. Shakhbiev I Kh, Shakhbiev Kh (2015) Ecology-epizootological analysis of jackal helminthes in the Chechen Republic. J Questions of regulatory legal regulation in veterinary medicine 4: 84-86.

16. Shikhalieva MA, Dokhov AA, Bittirov AM, Vologirov AS, Chilayev S Sh (2010) Parasitozoonoses of the Kabardino-Balkaria Republic. J Izvestiya Gorsky State Agrouniversity 47(1): 146-148.

17. Ardavova Zh M, Sarbasheva MM, Aripsheva BM (2010) Improvement of the sanitary-parasitological state of environmental objects in KabardinoBalkaria. Russian Parasitological Journal 4: 119-122.

18. Shikhalieva MA, Atabieva Zh A, Kolodiy IV, Sarbasheva MM, Bichieva MM (2012) Structure of parasitocenosis of the lowland belt of the north Caucasus region. J Veterinary Pathology 2(40): 109-113.

19. Bittirov AM (2013) Problem of epizootological of toxocarosis in animals and people in the regions of the Southern Federal District RF: Materials of the All-Russian Scientific and Practical conference Problems and perspective directions of applied biological science at the beginning of the XXI century. pp. 618.

20. Akieva OM, Bidzhiev AZ, Sarbasheva MM, Mantaeva S Sh, Shikhalieva MA (2012) Epizootological analysis of helminthes of domestic, stray and dogs in the Kabardino-Balkaria Republic. J Agrarian Science of the EuroNortheast 6(31): p. 58-61.

21. Bichieva MM, Atabieva Zh A, Kolodiy IV, Shikhalieva MA, Sarbasheva MM, et al. (2012) Forecasting epizootic and epidemic situation on zoonotic invasion in the south of Russia. J Veterinary Pathology 1(39): 119-122.

22. Bittirov AM (1999) Formation of helminthological complexes of animals in the Central Caucasus and development of methods for regulating the number of trematodes. Abstract of the dis, publishing house VIGIS, p. 43.

23. Sarbasheva MM (2010) Distribution and characteristics of cestode Echinococcus granulosus in dogs in the natural and climatic zones of the Kabardino-Balkaria Republic. J Izvestiya Gorsky State Agrarian University 47(1): 152-156

24. Bittirov AM (2013) An epidemiological situation on helminthoses of animals and the person in Kabardino-Balkarian Republic. Materials of the All Russian Scientific and Practical Conference. Moscow, p. 82-86.

\section{ISSN: 2574-1241}

DOI: 10.26717/BJSTR.2019.19.003279

Bittirov AM. Biomed J Sci \& Tech Res

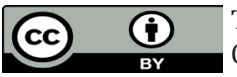

This work is licensed under Creative Commons Attribution 4.0 License

Submission Link: https://biomedres.us/submit-manuscript.php
25. Akieva OM, Sarbasheva MM, Mantaeva S Sh, Shikhalieva MA (2012) Ecologic specific and epizootological characteristic of wolf helminthes in the Kabardino-Balkaria Republic. J Agrarian Science of the EuroNortheast 5(30): 58-61.

26. Zalikhanov M Ch, Begieva SA (2018) Modern biological threats and world regulation to provide biosafety of animal products. Breeding on modern populations of domestic dairy cathedral as a basis of import substitution of animal production. Materials of the All-Russian Scientific Conf. with International Participation. Belgorod, pp. 245-253.

27. Kabardiev S Sh (2014) Veterinary and sanitary problems of regional pathology of fasciolosis of sheep and goats in the region North Caucasus and new methods for their elimination. Scientific-practical publication. Makhachkala pp. 198.

28. Thakakhova AA, Bittirova AA, Berezhko VK (2017) The species composition of helminthes and the contamination of sheep in the mountain tracts of Kabardino-Balkaria at an altitude of 1200-2500 m. Sea Theory and practice of combating parasitic diseases 18: 492-495.

29. Kabardiev S Sh, Begieva SA, Karpuschenko KA, Bittirova AA, Begiev S $\mathrm{Zh}$, et al. (2016) Anthelmintic agent for the treatment and prevention of fasciolesis, dicrocoeliosis and paramphistomatosis of cattle and small ruminants. Patent for the invention RUS 2612013 01.25.201601.

30. Bittirov AM, Kabardiev S Sh, Gazimagomedov MG, Magomedov OA, Begiev S Zh, et al. (2014) Integrated method of treatment of cattle fasciolesis. Patent for invention RUS 258421212.8.

31. Kabardiev S Sh, Magomedov OA, Musaev ZG, Eldarova L Kh, Begiev $\mathrm{S} \mathrm{Zh}$, et al. (2015) The effectiveness of new compositions based on albendazole and fenbendazole in intestinal sheep nematodoses. Theory and practice of combating parasitic diseases 16: 57-58.

32. Begiev S Zh, Bittirova AA, Kabardiev S Sh, Eldarova L Kh (2015). Embryotropic properties of the new composition of fenbendazole and albendazole (panaverm plus). Russian Parasitologica Journal 3: 86-88.

33. Uspensky AV, Kabardiev S Sh (2014) Problems of regional pathology and prevention of dangerous zoonoses in the region of the Central Caucasus. Caspian Zonal Vet. Research Institute. Makhachkala pp. 310-314.

34. Bittirova AA, Kabardiev S Sh, Begiev S Zh, Shakhbiev Kh (2016) New complex treatment of chronic fasciolesis of domestic goats. Proceedings of the All-Russian correspondence scientific-practical conference, pp. 111-116.

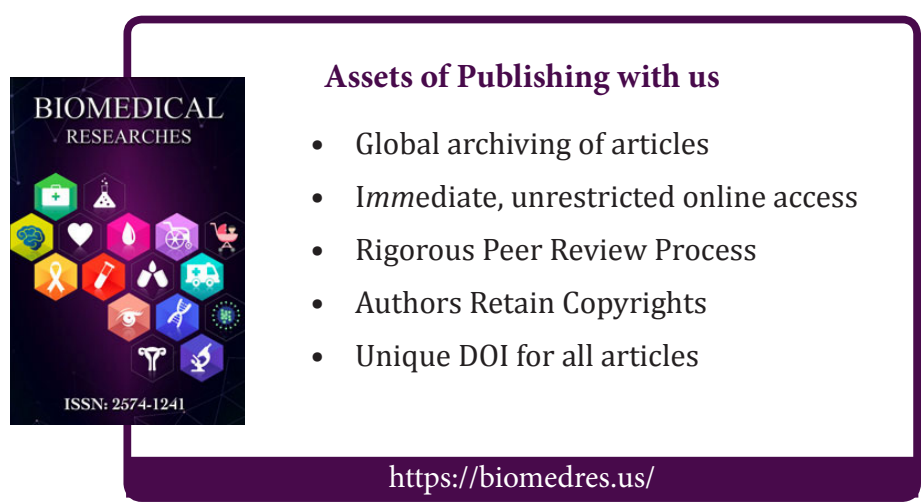

